\title{
ARTIKEL REVIEW \\ STUDI POTENSI LIMBAH TEMBAKAU MENJADI BIO-OIL MENGGUNAKAN METODE FAST-PYROLYSIS SEBAGAI ENERGI TERBARUKAN
}

\author{
Rafiqi Rajauddin Amin, Rimbi Rodiyana Sova, Dewinta Intan Laily, Dina Kartika Maharani* \\ Jurusan Kimia, Universitas Negeri Surabaya, Jl. Ketintang, Kota Surabaya, Indonesia \\ *Email: dinakartika@unesa.ac.id
}

\begin{abstract}
Abstrak
Perkembangan industri yang semakin pesat menyebabkan kebutuhan bahan bakar dan energi semakin meningkat khususnya bahan bakar fosil (petroleum). Hal tersebut berdampak terhadap terjadinya krisis energi. Biomassa menjadi perhatian khusus sebagai salah satu sumber energi terbarukan untuk mengatasi krisis energi yang terjadi saat ini. Biomassa terdiri dari hemiselulosa, selulosa, dan lignin yang dapat dikonversi menjadi cairan (bio-oil)dari pyrolisis. Salah satu limbah yang dapat dikonversi menjadi bio-oil yaitu limbah tembakau. Limbah tembakau dihasilkan lebih dari 2 juta ton setiap tahunnya. Limbah tersebut memiliki kandungan yang berpotensi diolah lebih lanjut menjadi bio-oilmenggunakan metode fast-pyrolysis dengan langkah-langkah pembuatan bio-oil secara efisien dan berkualitas. Adapun hasil bio-oil dari limbah tembakau menggunakan metode fast pyrolysis memiliki nilai karbon, hidrogen, nitrogen, oksigen, dan senyawa organik lain serta rasio H/C lebih besar dari pada hasil bio-oil limbah tembakau menggunakan metode low pyrolysis. Dimana bio-oil limbah tembakau menggunakan metode fast-pyrolysis memiliki nilai kalor yang tinggi setara dengan distribusi hidrokarbon dari biodiesel, yang berarti memiliki potensi sebagai energi alternatif pengganti petroleum. Potensi sebagai bahan bakar pengganti petroleum juga harus dimbangi dengan produksi yang cepat dan efisien, produksi bio-oil dapat dimaksimalkan dengan pemillihan reactor dan suhu optimum yang digunakan.
\end{abstract}

Kata kunci: Limbah, Tembakau, Bio-Oil, Energi Terbarukan, Fast-pyrolisis

\begin{abstract}
The rapid development of industry causes the need for fuel and energy to increase, especially fossil fuels (petroleum). This has the effect of an energy crisis. Biomass is of particular concern as one of the renewable energy sources to address the current energy crisis. Biomass consists of hemiselulose, cellulose, and lignin that can be converted into liquids (bio-oils) of pyrolysis. One of the wastes that can be converted into bio-oil is tobacco waste. Tobacco waste is produced by more than 2 million tons eachs. The waste has the potential to be further processed into bio oil using fast pyrolysis method with efficient and quality bio-oil manufacturing measures. The bio-oil results from tobacco waste using the fast pyrolysis method have values of carbon, hydrogen, nitrogen, oxygen and other organic compounds and the $\mathrm{H} / \mathrm{C}$ ratio is greater than the yield of tobacco waste bio-oil using the low pyrolysis method. Where the bio-oil of tobacco waste using the fast pyrolysis method has a high heating value equivalent to the distribution of hydrocarbons from biodiesel, which means it has the potential as an alternative energy to replace petroleum. The potential as a substitute fuel for petroleum must also be balanced with fast and efficient production, maximizing bio-oil production by selecting the reactor and the optimum temperature used.
\end{abstract}

Keywords: Waste, Tobacco, Bio-Oil, Renewable Energy, Fast-pyrolisis 


\section{Pendahuluan}

Pesatnya pertumbuhan penduduk yang diiringi dengan meningkatnya kemajuan industrimenyebabkan kebutuhan akan bahan bakar dan energi semakin meningkat khususnya bahan bakar fosil (petroleum). Hal tersebut berdampak pada berkurangnya persediaan cadangan petroleum di alam karena krisis energi yang juga menghambat kegiatan ekonomi. Selain itu penggunaan bahan bakar fosil menjadi salah satu penyebab utama pencemaran lingkungan dan pemanasan global. Berdasarkan peraturan pemerintah No. 79/2014 tentang Kebijakan Energi Nasional menyatakan bahwa pada tahun 2025 target peran energi baru dan terbarukan paling sedikit $23 \%$ pada tahun 2025 dan $31 \%$ pada tahun 2050 diimbangi dengan pengurangan peran minyak bumi kurang dari 25\% pada tahun 2025 dan kurang dari $20 \%$ pada tahun 2050.Hal inilah yang mendorong untuk mengembangkan energi terbarukan yang lebih efisien dan ramah lingkungan sebagai pengganti petroleum.

Biomassa menjadi perhatian khusus sebagai salah satu sumber energi terbarukan untuk mengatasi krisis energi yang terjadi saat ini. Kandungan biomassa yakni hemiselulosa, selulosa, dan lignin dan sejumlah kecil spesies organik dan anorganik lainnya tergantung pada jenis biomassa. Sumber daya biomassa biasanya dalam bentuk kayu dan limbah kayu, tanaman pertanian dan produk samping limbahnya, limbah padat kota, limbah proses pulp, dan sebagainya. Biomassa dapat dikonversi menjadi cairan (bio-oil), padat (bio-char), dan produk-produk gas dari pyrolysis(Akalina \& Karagöz, 2011).
Salah satu tanaman pertanian yang berpotensi untuk dikonversi menjadi biomassa yaitu tembakau. Komoditas tembakau tersebar di beberapa provinsi di Indonesia yang dimanfaatkan dalam berbagai industri rokok, kosmetik, obatobatan. Tembakau yang digunakan sebagai bahan utama dalam industri rokok hanya menggunakan daunnya dan menyisakan batang, akar, ranting dan daun kecil sebagai limbah pertanian. Liu et al., (2015) menyatakan bahwa batang tembakau memiliki kandungan nikotin sebesar 0,26\%, selulosa dan lignin berturut-turut sebesar $56,10 \%$ dan $15,11 \%$. Kandungan tersebut berpotensi besar sebagai bio-oil yang merupakan energi alternatif terbarukan dan ramah lingkungan daripada bahan bakar fosil (minyak bumi)(Rahmatullah, dkk, 2019).

Bio-oil merupakan senyawa oksigenat organik yang berbeda-beda dan tidak seperti bahan bakar minyak bumi pada umumnya. Hal ini karena tingginya kadar air, sekitar $15-20 \%$ yang berfungsi juga sebagai pengikat ratusan molekul yang berbeda yang disebut sebagai emulsi mikro. Crude bio-oil dapat digunakan sebagai pemanas rumah tangga atau boiler untuk pengeringan dan dapat ditingkatkan menjadi bahan bakar yang mempunyai nilai kalor yang lebih tinggi dan dapat digunakan untuk berbagai kebutuhan dalam industri kimia (oleokimia), seperti petroleumfuel (Wibowo, 2020).

Metode yang digunakan untuk pembuatan bio-oil dari biomassa melalui thermochemical process yaitu pyrolysis. Pyrolysis merupakan proses dekomposisi bahan kimia organik melalui tahap 
pemanasan tanpa atau sedikit oksigen atau reagen lainnya dimana material mentah akan mengalami pemecahan struktur kimia menjadi gas (Ridhuan et al., 2019). Metode pyrolysis sangat baik karena memaksimalkan senyawa lignin dan selulosa yang dihasilkan dari tumbuhan untuk menghasilkan bahan bakar cair. Penggunaan katalis dapat diaplikasikan pada proses pyrolysis dengan sebutan pyrolysis katalitik. Teknik pyrolysis yang berbeda memicu perbedaan dalam kuantitas dan kualitas produk yang dihasilkan. Bio-oil memiliki kandungan nitrogen dan sulfur yang rendah, dapat digunakan sebagai bahan bakar di beberapa mesin dan boiler yang dimodifikasi. Selain itu, minyak pyrolysis kaya akan senyawa organik yang memeberikan nilai tambah (Barla \& Kumar, 2019).

Jenis pyrolysis yang saat ini berkembang untuk menghasilkan bio-oil yaitu melalui proses fast pyrolisis. Proses fast pyrolisis dilakukan pada suhu antara $400^{\circ} \mathrm{C}-600{ }^{\circ} \mathrm{C}$ dengan lama pemanasan sekitar 0,5-2 detik.Kelebihan proses fast pyrolisis yaitu produk cair (Bio-oil) lebih banyak daripada jenis pyrolysis yang lain. Bio-oil dari fast pyrolisis dapat memberikan nilai kalor tinggi yang memiliki distribusi hidrokarbon yang serupa dengan diesel standar (Barla \& Kumar, 2019). Beberapa teknologi pyrolysis cepat (fast pyrolysis) antara lain bubbling fluidized bed, circulating fluidized bed reactor, rotating cone pyrolyzer, ablative pyrolysis, vacuum pyrolysis, dan auger reactor. Selain itu mulai dikembangkan juga free fall yang sudah dipanaskan pada suhu antara $400-700^{\circ} \mathrm{C}$. Produk yang dihasilkan fast pyrolisis selain cairan bio-oil, akan dihasilkan juga arang dan gas (Wibowo \& Hendra, 2015).

Berdasarkan beberapa uraian diatas, penulisan artikel review ini bertujuan untuk memberikan telaah literatur mengenai cara pembuatan bio-oil dari tembakau menggunakan fast-pyrolysis serta mengetahui kandungan bio-oil tembakau yang dihasilkan pada proses fast-pyrolysis.

\section{Metode Review}

Metode yang digunakan adalah melalui studi literatur yang telah dirangkum dari artikel-artikel yang relevan dengan proses pyrolysis menggunakan limbah tembakau. Pembahasan pada artikel review disusun secara narrative untuk menunjukkan bahwa proses pyrolysis limbah tembakau menggunakan metode fast pyrolysis menghasilkan persen bio oil yang lebih tinggi.

\section{Hasil kajian dan Pembahasan Limbah Tembakau}

Tanaman tembakau tersebar sangat luas di Indonesia. Berdasarkan data statistik Kementerian Pertanian Republik Indonesia tahun 2020, luas lahan tanaman tembakau mencapai total 204.961 Ha dengan kisaran populasi tanaman tembakau per hektar lahan adalah 22.000 pohon dan berat tembakau sekitar 0,5 kg. Jika ditotal tahun 2020 limbah pohon tembakau mencapai 2.302.268,36 ton.

Tabel 1 menunjukkan kandungan limbah tembakau yang berpotensi untuk dijadikan biomassa. Kandungan biomassa yakni hemiselulosa, selulosa, dan lignin dan sejumlah kecil spesies organik dan anorganik lainnya tergantung pada jenis biomassa. 
Tabel 1. Karakteristik Limbah Tembakau

\begin{tabular}{|c|c|c|}
\hline $\begin{array}{l}\text { Hasil analisis akhir(kering } \\
\text { dan bebas abu (daf)) }\end{array}$ & Berat $(\%)$ & Referensi \\
\hline $\mathrm{C}$ (berat\%) & $32.66-46.96$ & $\begin{array}{l}\text { (B. Liu et al., 2013), (Cardoso et al., 2011), } \\
\text { (Chen et al., 2016), (Onorevoli et al., 2018), } \\
\text { (Y1ldz \& Ceylan, 2019), (Yang et al., 2012), } \\
\text { (Wu et al., 2015) }\end{array}$ \\
\hline $\mathrm{H}($ berat $\%)$ & $4.37-8.54$ & $\begin{array}{l}\text { (B. Liu et al., 2013), (Cardoso et al., 2011), } \\
\text { (Chen et al., 2016), (Onorevoli et al., 2018), } \\
\text { (Y1ldı \& Ceylan, 2019), (Yang et al., 2012), } \\
\text { (Wu et al., 2015) }\end{array}$ \\
\hline $\mathrm{N}($ berat $\%)$ & $0.81-6.85$ & $\begin{array}{l}\text { (B. Liu et al., 2013), (Cardoso et al., 2011), } \\
\text { (Chen et al., 2016), (Onorevoli et al., 2018), } \\
\text { (Y1ldı \& Ceylan, 2019), (Yang et al., 2012), } \\
\text { (Wu et al., 2015) }\end{array}$ \\
\hline $\mathrm{O}(\text { berat } \%)^{\mathrm{a}}$ & $29.08-49.96$ & $\begin{array}{l}\text { (B. Liu et al., 2013), (Cardoso et al., 2011), } \\
\text { (Chen et al., 2016), (Onorevoli et al., 2018), } \\
\text { (Y1ldı \& Ceylan, 2019), (Yang et al., 2012), } \\
\text { (Wu et al., 2015) }\end{array}$ \\
\hline S & $0.04-0.76$ & $\begin{array}{l}\text { (B. Liu et al., 2013), (Cardoso et al., 2011), } \\
\text { (Chen et al., 2016), (Onorevoli et al., 2018), } \\
\text { (Y1ldı \& Ceylan, 2019), (Yang et al., 2012), } \\
\text { (Wu et al., 2015) }\end{array}$ \\
\hline Rasio atom $\mathrm{H} / \mathrm{C}$ & 1.89 & (Onorevoli et al., 2018) \\
\hline Rasio atom $\mathrm{O} / \mathrm{C}$ & 0.71 & (Onorevoli et al., 2018) \\
\hline Nilai kalor $(\mathrm{MJ} / \mathrm{kg})$ & $11.30-20.43$ & $\begin{array}{l}\text { (Chen et al., 2016)(Onorevoli et al., 2018), } \\
\text { (Y1ldiz \& Ceylan, 2019), (Yang et al., 2012), } \\
\text { (Wu et al., 2015) }\end{array}$ \\
\hline Hasil analisis proksimat & Berat $(\%)$ & Referensi \\
\hline
\end{tabular}




\begin{tabular}{|c|c|c|}
\hline $\begin{array}{l}\text { Abu (berat } \% \text {, keadaan } \\
\text { kering) }\end{array}$ & $5.20-24.33$ & $\begin{array}{l}\text { (B. Liu et al., 2013), (Chen et al., 2016), } \\
\text { (Y1ldı \& Ceylan, 2019), (Yang et al., 2012), } \\
\text { (Wu et al., 2015) }\end{array}$ \\
\hline $\begin{array}{l}\text { Kelembaban (berat } \% \text {, yang } \\
\text { diterima) }\end{array}$ & $2.83-9.40$ & $\begin{array}{l}\text { (B. Liu et al., 2013), (Chen et al., 2016), } \\
\text { (Y1ld1z \& Ceylan, 2019), (Yang et al., 2012), } \\
\text { (Wu et al., 2015) }\end{array}$ \\
\hline $\begin{array}{l}\text { Volatil (berat } \% \text {, keadaan } \\
\text { kering) }\end{array}$ & $59.75-70.20$ & $\begin{array}{l}\text { (B. Liu et al., 2013), (Chen et al., 2016), } \\
\text { (Y1ld1z \& Ceylan, 2019), (Yang et al., 2012), } \\
\text { (Wu et al., 2015) }\end{array}$ \\
\hline Karbon tetap ${ }^{\mathrm{a}}$ & $6.14-17.55$ & $\begin{array}{l}\text { (B. Liu et al., 2013), (Chen et al., 2016), } \\
\text { (Y1ldı \& Ceylan, 2019), (Yang et al., 2012), } \\
\text { (Wu et al., 2015) }\end{array}$ \\
\hline Analisis struktur & Berat $(\%)$ & Referensi \\
\hline Lignin & $6.51-18.63$ & (B. Liu et al., 2013), (Chen et al., 2016) \\
\hline Hemiselulosa & $5.05-11.78$ & (B. Liu et al., 2013), (Chen et al., 2016) \\
\hline Pektin & 15.21 & (Chen et al., 2016) \\
\hline Minyak & 2.82 & (B. Liu et al., 2013), \\
\hline Selulosa & $39.01-26.43$ & (B. Liu et al., 2013), (Chen et al., 2016) \\
\hline
\end{tabular}

Produk pyrolysis bergantung pada parameter proses serta komposisi bahan baku. Parameter proses yang penting diantaranta adalah suhu operasi, laju pemanasan, ukuran partikel, waktu tinggal volatil dan arang, dan keberadaan katalis. Bagian fisik dan kimia yang penting dari bahan baku seperti kandungan volatil, kelembaban, abu juga memengaruhi hasil produk pyrolysis(Hassan et al., 2015).

\section{Pyrolysis}

Pyrolysis adalah dekomposisi bahan kimia organik melalui proses pemanasan tanpa atau sedikit oksigen yang terjadi pada suhu antara 350-750 ( Kasim, F, et al, 2015; Cahyono, 2013; Astuti,D.H, et al., 2018; Herliati et al., 2019; Putra, A.E., et al., 2016; Ratnani \& Widiyanto, 2018; Syamsudin et al., 2016; Wibowo, 2016; Yusrizal dan Idris, 2016). Pada saat pemanasan material padat akan mengalami pemecahan struktur kimia menjadi gas (Herliati et al., 2019; Nurnasari dan Subiyakto, 2019; Ridhuan et al., 2019). 
Proses ini melepas 3 jenis produk, yaitu cair (Bio-oil), padat (arang), dan gas (Cahyono, 2013, Fachrizal, N, et al, 2012; Kasim, F, et al, 2015; Putra, A.E, et al., 2016; Ridhuan et al., 2019; Syamsudin et al., 2016). Jenis gas yang terbentuk dari proses pyrolysis bervariasi yaitu $\mathrm{CO}, \mathrm{CO}_{2}, \mathrm{H}_{2}, \mathrm{H}_{2} \mathrm{O}$, dan $\mathrm{CH}_{4}$ (Cahyono, 2013; Kasim, F, et al, 2015; Chen et al., 2016; B. Liu et al., 2013; Ratnani \& Widiyanto, 2018; Syamsudin et al., 2016). Hasil dari pyrolysis memiliki kandungan yang berbeda-beda, hal ini disebabkan oleh beberapa faktor antara lain suhu (Astuti, D.H., et al, 2018; Kasim, F, et al, 2015; Herliati et al., 2019; Mufandi et al., 2019; Fachrizal, N, et al, 2012; Qiram et al., 2015), jenis bahan ( Kasim, F, et al, 2015; Astuti, D.H., et al, 2018), jenis reaktor (Herliati et al., 2019), waktu (Astuti D.H,et al, 2018; Herliati et al., 2019;. Fachrizal, N. et al, 2012) dan jenis pyrolysis (Kasim, F, et al, 2015.

Pyrolysis adalah kasus khusus dari thermolysis terkait dengan proses kimia charring dan yang paling sering digunakan yaitu bahan organik. Proses pyrolysis dikategorikan menjadi 4 tipe yaitu pyrolysis lambat atau slow pyrolysis (Cahyono, 2013; Astuti,D.H, et al. 2018; Kasim, F, et al, 2015; B. Liu et al., 2013; Mufandi et al., 2019; Syamsudin et al., 2016; Wibowo, 2016; Wibowo dan Hendra, 2015), pyrolysis cepat atau fast pyrolysis (Cahyono, 2013; Chumsawat dan Tippayawong, 2020; Astuti, D.H, et al, 2018; B. Liu et al., 2013; Mufandi et al., 2019; Fachrizal, N, et al, 2012; Syamsudin et al., 2016; Wibowo, 2016; Wibowo \& Hendra, 2015), pyrolysis Kilat atau flash pyrolysis (Fachrizal,N, et al, 2012; Wibowo, 2016; Kasim, F, et al, 2015), pyrolysis katalitik biomassa (Akalina dan
Karagöz, 2011; Kim et al., 2020; Ridhuan et al., 2019).

Secara umum metode yang sering digunakan dalam proses dekomposisi biomassa adalah metode slow dan fast pyrolysis, yang menjadi perbedaan diantara keduanya adalah temperature, waktu alir, dan produk yang dihasilkan. Slow pyrolysis memiliki tingkat pemanasan lambat dari 0,1$1^{\circ} \mathrm{C} /$ detik (Kasim, F, et al, 2015), ada juga yang menyebutkan 5-7 K/menit (Ridhuan et al., 2019). Metode pyrolysis ini menghasilkan sedikit bio-oil dan lebih banyak arang dan gas (Ridhuan et al., 2019; Wijayanti \& Sasongko, 2012). Pyrolysis cepat dicapai melalui pemanasan cepat antara 10 sampai $1000^{\circ} \mathrm{C} /$ detik (Ridhuan et al., 2019; Wijayanti \& Sasongko, 2012), waktu tinggal pendek yaitu kurang dari 2 detik ( Kasim, F, et al, 2015.; Ridhuan et al., 2019), suhu 400-650 ${ }^{\circ} \mathrm{C}$, dan dengan pendinginan yang cepat dari uap (Dickerson, 2013). pendinginan yang cepat sangat penting untuk memperoleh produk dengan berat molekul tinggi sebelum akhirnya terkonversi menjadi senyawa gas yang memiliki berat molekul rendah. Dengan cara ini dapat dihasilkan produk bio-oil 70 hingga $75 \%$ dari berat awal biomassa (Ridhuan et al., 2019; Wijayanti dan Sasongko, 2012).

Bio-oil adalah cairan berwarna kehitaman hasil dari pyrolysis biomassa (Cahyono, 2013; Ridhuan et al., 2019; Wibowo dan Hendra, 2015)yang memiliki berat molekul tinggi dan mudah menguap pada suhu pyrolysis dan terkondensasi pada suhu ruang (Syamsudin et al., 2016). Kandungan dari bio-oil sendiri bervariasi tergantung dari kandungan biomassa(Astuti, D.H., 2018; Kasim, F, et al, 2015; Herliati et 
al., 2019) dan suhu pyrolysis(Chen et al., 2016; F Kasim, F, et al, 2015; Nurnasari \& Subiyakto, 2019). Adapun secara umum biooil dari biomassa yang komposisi utamanya adalah selulosa, hemiselulosa, dan lignin mengandung senyawa turunan dari fenol, senyawateroksigenasi tinggi (Putra, A.E, et al, 2016; Syamsudin et al., 2016), hidroksialdehida, hidroksiketon, asam karboksilat, senyawa yang mengandung cincin furan/pyran, gula-gula anhidro, senyawa fenolik dan fragmen oligomer dari polimer lignoselulosa ( Kasim, F, et al, 2015.; Wibowo \& Hendra, 2015).

Adapun kandungan bio-oil dari limbah tembakau sangat bervariasi bergantung dari kandungan, suhu dan motode pyrolysis, dari data Cardoso, et al (2013) dilaporkan bahwa pada pyrolysis daun tembakau murni (tanpa tambahan $\mathrm{ZnCl}_{2}$ dan $\mathrm{MgCl}_{2}$ ) pada suhu $400^{\circ} \mathrm{C}$ senyawa utama yang dihasilkan adalah nikotin, sedangkan senyawa lain yang terdeteksi antara lain heksadekana, dodekana, tridekana, 3,3-dimetilbutana-2-ol dan limonene, sedangkan pada suhu $500^{\circ} \mathrm{C}$ dihasilkan senyawa nikotin, asam asetat, heksadekana, senyawa-senyawa hidrokarbon seperti keton, alkohol, aldehid dan senyawa aromatic turunan nikotin antara lain pyrol dan piridin (Cardoso, et al., 2011; Nurnasari dan Subiyakto, 2019)

Berdasarkan penelitian-penelitian terdahulu, diketahui kandungan bio-oil bergantung pada jenis kandungan biomassa (Mukhtar, P, et al, 2016; Syamsudin et al., 2016). Adapun pengaruh metode pengoperasian pyrolysis dengan cara fast pyrolysis dan slow pyrolysis berdasarkan penelitian dari Pütün et al. (2007) dan Bridgwater et al. (2007) dijabarkan pada Tabel 2.

Tabel 2. Perbandingan Hasil Fast Pyrolysis dan Slow Pyrolysis

\begin{tabular}{|c|c|c|c|c|c|c|}
\hline \multirow{2}{*}{$\begin{array}{c}\text { Komponen } \\
(\%)\end{array}$} & \multicolumn{2}{|c|}{ Tembakau } & \multicolumn{4}{c|}{ Tumbuhan Mallee } \\
\cline { 2 - 7 } & $\begin{array}{c}\text { Fast } \\
\text { pyrolysis }\end{array}$ & $\begin{array}{c}\text { Slow } \\
\text { pyrolysis }\end{array}$ & $\begin{array}{c}\text { Fast } \\
\text { pyrolysis } \\
500^{\circ} \mathrm{C}\end{array}$ & $\begin{array}{c}\text { Slow } \\
\text { pyrolisis } \\
420^{\circ} \mathrm{C}\end{array}$ & $\begin{array}{c}\text { Slow } \\
\text { pyrolysis } \\
500{ }^{\circ} \mathrm{C}\end{array}$ & $\begin{array}{c}\text { Slow } \\
\text { pyrolysis } \\
600{ }^{\circ} \mathrm{C}\end{array}$ \\
\hline Karbon & 66.02 & 64.94 & 43,9 & 28,13 & 28,00 & 27,39 \\
\hline Hydrogen & 8.50 & 7.92 & 7,4 & 9,38 & 9,38 & 9,55 \\
\hline Nitrogen & 3.02 & 2.28 & 0,07 & 0,03 & - & - \\
\hline Oksigen & 27.76 & 25.32 & 48,6 & 62,5 & 62,7 & 63,1 \\
\hline Rasio H/C & 1.53 & 1.47 & - & - & - & - \\
\hline HHV & 29,59 & 28,83 & 14,4 & 6,8 & 6,4 & 7,1 \\
\hline Referensi & $($ Pütü et al., 2007) & \multicolumn{3}{|c|}{$($ Bridgwater et al., 2007) } \\
\hline
\end{tabular}


Dari data Tabel 2 menunjukkan bahwa pengolahan tembakau menjadi bio-oil menggunakan metode fast pyrolysis memiliki hasil yang lebih tinggi dibandingkan menggunakan metode slow pyrolysis. Faktor yang mempengaruhi perbedaan hasil produk keduanya disebabkan oleh tingkat pemanasan, temperature, dan waktu alir. Hal ini menunjukkan bahwa konversi limbah tembakau menggunakan metode fast pyrolysis adalah yang paling mendekati standar atau memenuhi syarat untuk dijadikan bahan bakar pengganti petroleum. Spesifikasi standart bio oil yang dapat digunakan untuk bahan bakar dijabarkan pada Tabel 3.

Tabel 3. Spesifikasi Bio-oil untuk bahan bakar

\begin{tabular}{|l|l|l|}
\hline \multicolumn{1}{|c|}{ Properties } & \multicolumn{1}{|c|}{ Spesifikasi } & \multicolumn{1}{c|}{ Keterangan } \\
\hline HHV & $\begin{array}{l}>70.000 \\
\text { BTU/Gal }\end{array}$ & $\begin{array}{l}\text { Metode DINS } \\
51900\end{array}$ \\
\hline Kandungan air & $<25 \% \quad$ ASTM D1744 \\
\hline Viskositas & $\begin{array}{l}10-150 \quad \mathrm{cP} \quad @ \\
50^{\circ} \mathrm{C}\end{array}$ & ASTM D445 \\
\hline Spesifik gravity & $1,2 @ 15^{\circ} \mathrm{C}$ & ASTM D4052 \\
\hline $\begin{array}{l}\text { Elemental } \\
\text { analisis: }\end{array}$ & Range & Average \\
\hline Karbon & $51,5-58,3$ & 54,5 \\
\hline Hydrogen & $5,5-6,8$ & 6,4 \\
\hline Nitrogen & $0,07-0,40$ & 0,2 \\
\hline Sulfur & $<0,07$ & 0,0005 \\
\hline Debu & $0,13-0,21$ & 0,16 \\
\hline
\end{tabular}

Sumber : Dynamotive (2006)

\section{Pyrolysis Tembakau}

Reaktor merupakan jantung dari setiap proses pyrolysis. Teknologi reaktor fastpyrolysis diantaranya fixed-bed reaktor (Akalina \& Karagöz, 2011), fluidized bed (Thu et al., 2020, Raymundo et al., 2020), fluidized bed pilot plants (Treedet \& Suntivarakorn, 2018), reaktor auger(Kapoor et al., 2017), ablative reaktor (Khuenkaeo \& Tippayawong, 2018). Kebanyakan reaktor pyrolysis, bahan baku biomassa perlu diproses menjadi ukuran kecil sekitar $2 \mathrm{~mm}$ (Khuenkaeo \& Tippayawong, 2018). Pyrolysis fluidized bed reactor lebih komplek daripada fixed bed reactor (Hassan et al., 2015). Tabel 4 berikut menyajikan data hasil fast pyrolysis tembakau.

Hasil data pada Tabel 4 menunjukkan bahwa hasil fast-pyrolysis dari setiap percobaan berbeda-beda tergantung pada perilaku yang diterapkan, pemilihan reaktor serta penggunaan 
suhu mempengaruhi hasil fast-pyrolysis yang dilakukan. Dalam Tabel 4 diketahui bahwa berdasarkan penelitian-penelitian yang sudah dilakukan penggunaan bahan batang tembakau dengan menggunakan reaktor fluidized bed reactor dan suhu $400^{\circ} \mathrm{C}$ menghasilkan bio-oil $67 \%$ wt dimana bio-oil yang dihasilkan lebih tinggi dari pada penelitian-penelitian lainnya, sehingga dapat digunakan dalam acuan produksi bio-oil dari limbah tembakau (Yan, et al., 2018). Penelitian Xia, et al, 2020 yang juga menggunakan fluidized bed reactor dengan feed stock batang tembakau menghasilkan persentase bio oil yang lebih rendah.

Tabel 4. Hasil Konversi Tembakau Menggunakan Metode Fast Pyrolysis

\begin{tabular}{|c|c|c|c|c|c|c|}
\hline Feed stock & $\begin{array}{ll}\text { Suhu } & { }^{\circ} \mathrm{C} \\
\% \text { wt } & \end{array}$ & Reaktor & $\begin{array}{l}\text { Bio-oil } \\
\% w t\end{array}$ & $\begin{array}{l}\text { Bio-char } \\
\text { \%wt }\end{array}$ & Gas \% wt & Referensi \\
\hline $\begin{array}{l}\text { Batang } \\
\text { tembakau }\end{array}$ & 400 & $\begin{array}{l}\text { Fixed-bed } \\
\text { reactor }\end{array}$ & 48,86 & 39,74 & 11,40 & $\begin{array}{l}\text { (Akalina \& } \\
\text { Karagöz, } \\
\text { 2011) }\end{array}$ \\
\hline $\begin{array}{l}\text { Limbah } \\
\text { tembakaku }\end{array}$ & 500 & $\begin{array}{l}\text { Fixed-bed } \\
\text { reactor }\end{array}$ & 35,10 & 43,90 & 21,00 & $\begin{array}{l}\text { (Akalina \& } \\
\text { Karagöz, } \\
\text { 2011) }\end{array}$ \\
\hline Tembakau & 450 & $\begin{array}{l}\text { fixed-bed } \\
\text { reactor }\end{array}$ & 43,00 & - & - & $\begin{array}{l}\text { Chen et al., } \\
\text { 2016) }\end{array}$ \\
\hline $\begin{array}{l}\text { Benih } \\
\text { tembakau }\end{array}$ & 700 & $\begin{array}{l}\text { fixed bed } \\
\text { reactor } \\
\text { (quartz) }\end{array}$ & 40,90 & - & - & $\begin{array}{l}\text { Onorevoli et } \\
\text { al., 2017) }\end{array}$ \\
\hline $\begin{array}{l}\text { Batang } \\
\text { tembakau }\end{array}$ & 400 & $\begin{array}{l}\text { fluidized } \\
\text { bed reactor }\end{array}$ & 67,47 & - & - & $\begin{array}{l}\text { (Yan et al., } \\
2018)\end{array}$ \\
\hline $\begin{array}{l}\text { Daun } \\
\text { tembaakau }\end{array}$ & 400 & $\begin{array}{l}\text { fluidized } \\
\text { bed reactor }\end{array}$ & 60,95 & - & - & $\begin{array}{l}\text { (Yan et al., } \\
2018)\end{array}$ \\
\hline Tembakau & 600 & $\begin{array}{l}\text { Ablative } \\
\text { vacuum } \\
\text { reactor }\end{array}$ & 54 & $18-24$ & & $\begin{array}{l}\text { (Chumsawat } \\
\& \\
\text { Tippayawo }\end{array}$ \\
\hline $\begin{array}{l}\text { Daun } \\
\text { tembakau }\end{array}$ & 450 & $\begin{array}{l}\text { fluidized } \\
\text { bed reactor }\end{array}$ & 57,57 & - & - & $\begin{array}{l}\text { (Xia et al., } \\
2020)\end{array}$ \\
\hline $\begin{array}{l}\text { Batang } \\
\text { tembakaku }\end{array}$ & 400 & $\begin{array}{l}\text { fluidized } \\
\text { bed reactor }\end{array}$ & 64,14 & - & - & $\begin{array}{l}\text { ( Xia et al., } \\
2020)\end{array}$ \\
\hline
\end{tabular}

Pada feedstock yang sama yaitu batang tembakau dan suhu yang sama $400{ }^{0} \mathrm{C}$ penggunaan reaktor fluidized bed reactor pada penelitian ( Xia, et al., 2020) menunjukkan hasil yang lebih tinggi dibandingkan reaktor Fixed-bed pada penelitian (Akalina \& Karagöz, 2011). Penggunaan temperatur yang lebih tinggi yaitu $450 \quad{ }^{0} \mathrm{C}$ dengan feedstock daun tembakau menghasilkan 
persen berat bio oil yang cukup tinggoi yaitu 64\% (Xia, et al., 2020).

Beberapa contoh skema teknologi fastpyrolysis yang digunakan dalam pembuatan bio-oil limbah tembakau pada penelitian yang telah dilakukan disajikan pada Gambar 1, 2 dan 3.

Reaktor ablative pyrolisis seperti pada Gambar 1 didesain untuk mengoptimalkan kinerja pirolisis dan untuk menghasilkan hasil yang tinggi dari minyak nabati. Setiap Jenis reaktor memiliki karakteristik khusus, kapasitas menghasilkan minyak nabati, kelebihan dan keterbatasan. Reactor ablative pyrolysis ini dilakukan pada suhu $450-600^{\circ}$ C dalam skala laboratorium, dipanaskan secara eksternal, reaktor vakum ablatif, ditunjukkan pada Gambar 1. Pirolisis ablatif menawarkan kontrol yang baik pada uap yang dihasilkan dan mampu digunakan untuk biomassa berukuran lebih besar (Khuenkaeo dan Tippayawong, 2018).

Reaktor jenis lain yaitu reactor fluidized bed sepetti ditunjukkan pada Gambar 2. Yan et al. (2018) dalam penelitiannya menggunakan reactor fluidized bed reactor, dimana biomassa daun tembakau dan batang tembakau dimasukkan dalam reaktor sebanyak $2 \mathrm{~kg} / \mathrm{jam}$ di bawah suasana nitrogen inert dengan waktu tinggal dalam reaktor sekitar 3-4 detik. Sekitar $50 \mathrm{~g}$ feedstock dimasukkan ke dalam reaktor ablative pyrolysis menggunakan katup umpan yang dipasang di puncak. Reaktor berbentuk panci (diameter dalam 25 $\mathrm{cm}$ dan tinggi $4 \mathrm{~cm}$ ) dipanaskan dengan kompor gas dengan suhu pelat bawah sebesar 50 derajat dikontrol dengan pengontrol dan termokopel tipe-K diukur.
Fast pyrolysis menggunakan fluidized bed reactor menggunakan gas nitrogen yang dipanaskan sebelumnya oleh pemanas awal dan laju aliran dikontrol alirannya sebesar 2,8 $\mathrm{m}^{3} / \mathrm{jam}$. Biochar dipisahkan dari produk pirolisis melalui tahapantahapan pemisah dua siklon, kemudian gas yang dapat dikondensasikan dan gas yang tidak dapat dikondensasi melewati tiga kondensor, yaitu kondensor dinding, kondensor koil, dan penghancur siklon. Kondensor pertama dan kedua didinginkan dengan air. Biochar, bio-oil, dan noncondensable gas hasil pirolisis dikumpulkan dan diambil sampelnya masing-masing (Yan, et al, 2018).

Pada reactor jenis fixed bed, perapian reaktor terbuat dari tabung kuarsa dan itu dipanaskan secara eksternal oleh tungku cincin listrik, yang ditutupi dengan lapisan isolasi di luar. Panjang efektif reaktor adalah $1200 \mathrm{~mm}$ dengan diameter dalam $60 \mathrm{~mm}$. Tabung kuarsa dibagi menjadi zona pemanasan dan normal zona suhu 1 dan 2 di sepanjang arah aksial, seperti yang ditunjukkan pada Gambar 3. Tungku dipanaskan dengan kecepatan $10^{\circ} \mathrm{C} /$ menit sampai suhu akhir yang diinginkan dan dijaga agar tetap konstan. Tipe Termokopel $\mathrm{K}$ digunakan untuk mengukur profil suhu di zona pemanas perapian. Filter secara seri digunakan sebagai unit penghilang debu untuk pembersihan bahan bakar gas. Sebuah kondensor seri digunakan sebagai unit pendingin untuk pendinginan bahan bakar gas dan penangkapan tar. Bahan bakar gas dari reaktor memasuki unit pembersihan debu dan unit pendingin secara berurutan (Y. Yang et al., 2019). 


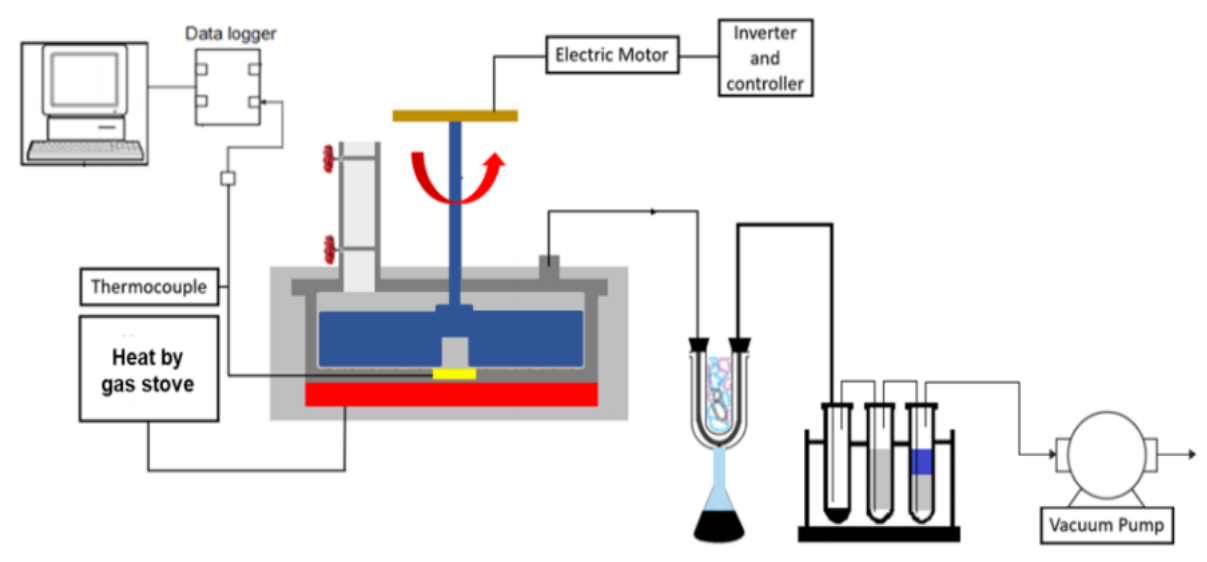

Gambar 1. Diagram Skema Ablative Pyrolysis

(Chumsawat \& Tippayawong, 2020).

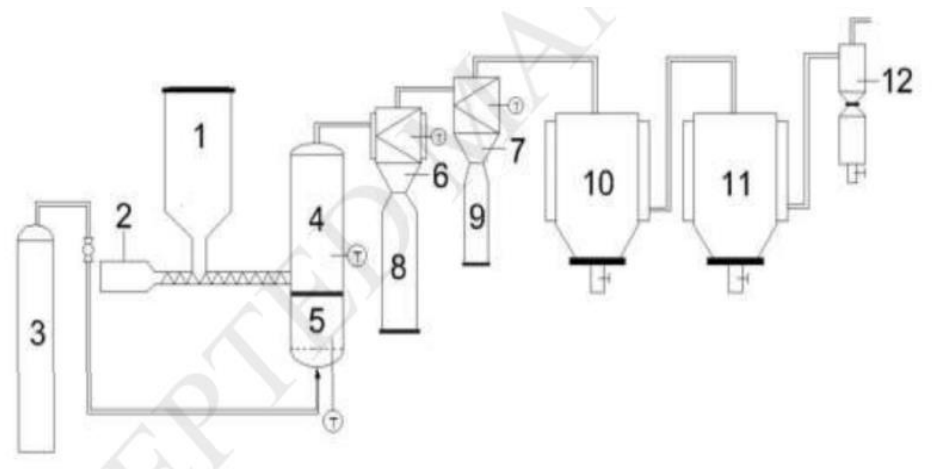

Gambar 2. Diagram Skema Fluidized Bed Pyrolysis

1: Feeder; 2: feed auger; 3: nitrogen; 4: fluidized bed; 5: preheater; 6, 7: cyclone separators; 8, 9: hoppers; 10, 11: condensers; 12: cyclone demisters; T: thermocouples

(Yan et al., 2018).

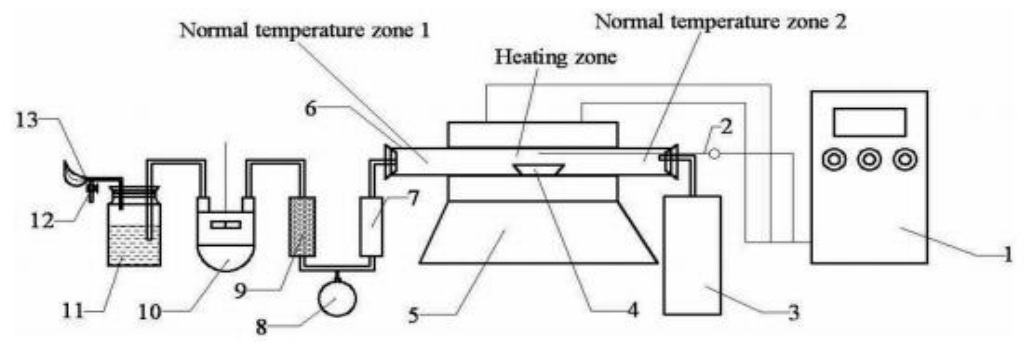

Gambar 3. Diagram Skema Fixed-Bed Pyrolysis 
. (1) Temperature controller; (2) thermocouple; (3) nitrogen gas tank; (4) porcelain boat; (5) electric furnace; (6) quartz tube reactor; (7) condenser; (8) tar collector; (9) filter; (10) flowmeter; (11) watersealed bottle; (12) to gas collector bag; (13) exhaust gas burner

(Y. Yang et al., 2019)

\section{Kesimpulan}

Berdasarkan hasil analisis data dapat disimpulkan bio-oil dari limbah tembakau menggunakan metode fast pyrolysis memiliki nilai karbon, hidrogen, nitrogen, oksigen, dan senyawa organik lain serta rasio $\mathrm{H} / \mathrm{C}$ lebih besar dari pada hasil bio-oil limbah tembakau menggunakan metode low pyrolysis. Dimana bio-oil limbah tembakau menggunakan metode fast pyrolysis

\section{Daftar Pustaka}

Akalina, M. K., \& Karagöz, S. (2011). Pyrolysis of tobacco residue. Part 2: Catalytic. BioResources, 6(2), 1773-1805. https://doi.org/10.15376/biores.6.2.17731805

Astuti, D.S, Sani, Yuandana, Y.G, Karlin. (2018). Pyrolysis Study Biochar ' S Characteristic From Tobacco Stem, Papaya Stem and Rice Straw With Pyrolysis Process. Jurnal Teknik Kimia, 12(2), 41-46

B. A. Bohm, "The Minor Flavonoids," in The Flavonoids: Advances in Research, J. B. Harborne and T. J. Mabry, Eds. London: Chapman \& Hall, 1994.

Barla, F. G., \& Kumar, S. (2019). Tobacco biomass as a source of advanced biofuels. Biofuels, 10(3), 335-346. https://doi.org/10.1080/17597269.2016.1 242684

Booker, C. J., Bedmutha, R., Scott, I. M., Conn, K., Berruti, F., Briens, C., \& Yeung, K. K. C. (2010). Bioenergy II: Characterization of the pesticide properties of tobacco biooil. International Journal of Chemical Reactor Engineering, 8. https://doi.org/10.2202/1542-6580.1939

Bridgwater, A. V., Carson, P., \& Coulson, M. memiliki nilai kalor yang tinggi setara dengan distribusi hidrokarbon dari biodiesel, yang berarti memiliki potensi sebagai energi alternatif pengganti petroleum. Potensi sebagai bahan bakar pengganti petroleum juga harus dimbangi dengan produksi yang cepat dan efisien, produksi bio-oil dapat dimaksimalkan dengan pemillihan reactor dan suhu optimum yang digunakan.

(2007). A comparison of fast and slow pyrolysis liquids from mallee. International Journal of Global Energy Issues, 27(2), 204-216. https://doi.org/10.1504/IJGEI.2007.01365 5

Cahyono, M. S. (2013). Pengaruh Jenis Bahan pada Proses Pyrolysis Sampah Organik menjadi Bio-Oil sebagai Sumber Energi Terbarukan. Jurnal Sains \&Teknologi Lingkungan, 5(2), 67-76. https://doi.org/10.20885/jstl.vol5.iss2.art1

Cardoso, C. R., Miranda, M. R., Santos, K. G., \& Ataíde, C. H. (2011). Determination of kinetic parameters and analytical pyrolysis of tobacco waste and sorghum bagasse. Journal of Analytical and Applied Pyrolysis, 92(2), 392-400. https://doi.org/10.1016/j.jaap.2011.07.013

Chen, H., Lin, G., Chen, Y., Chen, W., \& Yang, H. (2016). Biomass Pyrolytic Polygeneration of Tobacco Waste: Product Characteristics and Nitrogen Transformation. Energy and Fuels, 30(3), 1579-1588.

https://doi.org/10.1021/acs.energyfuels.5b 02255

Chumsawat, L., \& Tippayawong, N. (2020). Utilizing tobacco residues to generate bio- 
oil and biochar via ablative pyrolysis. Chemical Engineering Transactions, 78, 49-54. https://doi.org/10.3303/CET2078009

Hassan, M. M., Perves, M., Alam, M. J., Roy, A., \& Nabi, M. N. (2015). Design \& Construction of a Pyrolysis Reactor for Liquid Oil Production from Olive Seeds. Proceedings of the International Conference on Mechanical, Industrial and Materials Engineering 2015 (ICMIME2015), December.

Herliati, H., Prasetyo, S. B., \& Verinaldy, Y. (2019). Review: Potensi limbah Plastik dan Biomassa sebagai Sumber Energi Terbarukan Dengan Proses Pyrolysis. Jurnal Teknologi, 6(2), 85-98. https://doi.org/10.31479/jtek.v6i2.13

Kapoor, L., Mekala, A., \& Bose, D. (2017). Auger reactor for biomass fast pyrolysis: Design and operation. International Conference on 21 st Century Energy Needs - Materials, Systems and Applications, ICTFCEN 2016. https://doi.org/10.1109/ICTFCEN.2016.8 052749

Kasim, F; Fitrah, A.N; Hambali, E. (2016), Aplikasi Asap Cair pada Lateks. Jurnal PASTI, [S.1.], vol. 9, no. 1, April. 2016. ISSN 2598-4853

Khuenkaeo, N., \& Tippayawong, N. (2018). Bio-oil Production from Ablative Pyrolysis of Corncob Pellets in a Rotating Blade Reactor. IOP Conference Series: Earth and Environmental Science, 159(1). https://doi.org/10.1088/17551315/159/1/012037

Kim, Y., Shim, J., Choi, J. W., Jin Suh, D., Park, Y. K., Lee, U., Choi, J., \& Ha, J. M. (2020). Continuous-flow production of petroleum-replacing fuels from highly viscous Kraft lignin pyrolysis oil using its hydrocracked oil as a solvent. Energy Conversion and Management, 213(December 2019), 112728. https://doi.org/10.1016/j.enconman.2020. 112728

K. T. Sutar and P. U. Singare, "Study of Antioxidant Activity of Hindered Phenols in Bulk Oil and Thin Film Oxidation
Conditions in Lubricants," Rasayan $J$. Chem, vol. 11, no. 2, pp. 465-474, 2018.

Lin Yan. (2016) Agricultural Research Service U.S. Department Of Agriculture. [Online]. https://www.ars.usda.gov/plainsarea/gfnd/gfhnrc/docs/new

Liu, B., Li, Y. M., Wu, S. Bin, Li, Y. H., Deng, S. S., \& Xia, Z. L. (2013). Pyrolysis characteristic of tobacco stem studied by Py- GC/MS, TG-FTIR, and TG-MS. BioResources, 8(1), 220-230. https://doi.org/10.15376/biores.8.1.220230

Liu, Y., Dong, J., Liu, G., Yang, H., Liu, W., Wang, L., Kong, C., Zheng, D., Yang, J., Deng, L., \& Wang, S. (2015). Codigestion of tobacco waste with different agricultural biomass feedstocks and the inhibition of tobacco viruses by anaerobic digestion. Bioresource Technology, 189, 210-216.

https://doi.org/10.1016/j.biortech.2015.04 .003

Mufandi, I., Treedet, W., Singbua, P., \& Suntivarakorn, R. (2019). Produksi BioOil dari Rumput Gajah dengan Fast Pyrolysis menggunakan Circulating Fluidized Bed Reactor (CFBr) dengan Kapasitas $45 \mathrm{Kg} / \mathrm{H}$. CHEMICA: Jurnal Teknik Kimia, 5(2), 37. https://doi.org/10.26555/chemica.v5i2.12 484

N. Fachrizal, R. Mustafa, M. P. (2012). Proses Pyrolysis Biomasa Gelombang Mikro. 153-160.

Nurnasari, E., \& Subiyakto, S. (2019). Diversifikasi Produk Tembakau Non Rokok Diversification of Non-Cigarette Tobacco Products. Perspektif, 17(1), 40. https://doi.org/10.21082/psp.v17n1.2018. 40-51

Onorevoli, B., da Silva Maciel, G. P., Machado, M. E., Corbelini, V., Caramão, E. B., \& Jacques, R. A. (2018). Characterization of feedstock and biochar from energetic tobacco seed waste pyrolysis and potential application of biochar as an adsorbent. Journal of Environmental Chemical Engineering, 6(1), 1279-1287. https://doi.org/10.1016/j.jece.2018.01.039 
Onorevoli, B., Machado, M. E., Polidoro, A. D. S., Corbelini, V. A., Caramão, E. B., \& Jacques, R. A. (2017). Pyrolysis of Residual Tobacco Seeds: Characterization of Nitrogen Compounds in Bio-oil Using Comprehensive Two-Dimensional Gas Chromatography with Mass Spectrometry Detection. Energy and Fuels, 31(9), 94029407.

https://doi.org/10.1021/acs.energyfuels.7b 00405

Putra, A. E., Rahman, M., \& Aminy, A. (2018). Produksi Bahan Bakar Ramah Lingkungan Melalui Proses Pirolisis Limbah Ban. Jurnal Penelitian Enjiniring, 20(2), pp. 26-31. 1 . http://cot.unhas.ac.id/journals/index.php/j pe/article/view/17Pütün, A. E., Önal, E., Uzun, B. B., \& Özbay, N. (2007). Comparison between the "slow" and "fast" pyrolysis of tobacco residue. Industrial Crops and Products, 26(3), 307-314. https://doi.org/10.1016/j.indcrop.2007.03. 011

Qiram, I., Widhiyanuriyawan, D., \& Wijayanti, W. (2015). Energi Yang Dihasilkan Pyrolysis Serbuk Kayu Mahoni (Switenia Macrophylla ) Pada Rotary Kiln. J1 . MT . Haryono 167 , Malang 65145 , Indonesia ABSTRACT Pirolysis is thermochemical decomposition process of biomass into useful product . A method that ca. 8 .

Syamsudin, S., Purwati, S., Surachman, A., \& Wattimena, R. B. I. (2016). Pyrolysis Isotermal Sludge Cake Dan Pulp Reject Pabrik Pulp Kraft (Isothermal Pyrolysis Of Sludge Cake And Pulp Reject From Kraft Pulp Mill). Jurnal Selulosa, 6(02), 71-82. https://doi.org/10.25269/jsel.v6i02.90

Thu, K., Reungpeerakul, T., \& Sangwichien, C. (2020). Simulation of Reaction Kinetics and Heat Transfer Effects on Product Yields from Fast Pyrolysis of Oil Palm Empty Fruit Bunch Biomass in Fluidized Bed Reactor. Bioenergy Research. https://doi.org/10.1007/s12155-02010148-1

Treedet, W., \& Suntivarakorn, R. (2018).
Rahman, A. (n.d.). Uji Parameter Temperatur Dan Tekanan Vakum. 1-5.

Ratnani, R. D., \& Widiyanto. (2018). A Review of Pyrolisis of Eceng Gondok (Water hyacinth) for Liquid Smoke. E3S Web of Conferences, 73, 2-6. https://doi.org/10.1051/e3sconf/20187305 010

Raymundo, L. M., Espindola, J. S., Borges, F. C., Lazzari, E., Trierweiler, J. O., \& Trierweiler, L. F. (2020). Continuous fast pyrolysis of rice husk in a fluidized bed reactor with high feed rates. Chemical Engineering Communications, O(0), 1-11. https://doi.org/10.1080/00986445.2020.1 798937

Ridhuan, K., Irawan, D., \& Inthifawzi, R. (2019). Proses Pembakaran Pyrolysis dengan Jenis Biomassa dan Karakteristik Asap Cair yang Dihasilkan. Turbo : Jurnal Program Studi Teknik Mesin, 8(1), 69-78. https://doi.org/10.24127/trb.v8i1.924

Robinson T., The Organic Constituents of Higher Plants 6th Ed. North Amherst, MA: Cordus Press, 2010.

Siti Mariam Abdul Lathiff, Noraini Jemaon, Siti Awanis Abdullah, and Shajarahtunnur Jamil, "Flavonoids from Artocarpus anisophyllus and their Bioactivities," Natural Product Communications, vol. 10, no. 3, pp. 393-396, 2015.

Design and operation of a low cost biooil fast pyrolysis from sugarcane bagasse on circulating fluidized bed reactor in a pilot plant. Fuel Processing Technology, 179(October), 17-31. https://doi.org/10.1016/j.fuproc.2018.06. 006

Wibowo, S. (2016). Karakteristik Bio-Oil Dari Limbah Industri Hasil Hutan Menggunakan Pyrolysis Cepat. Jurnal Penelitian Hasil Hutan, 34(1), 61-67. https://doi.org/10.20886/jphh.2016.34.1. 61-76

Wibowo, S. (2020). Karakte Ristik Bio-Oil Dari Limbah Industri Hasil Hutan Me Nggunakan Pyrolysis Ce Pat ( Characteristics of Bio-oil Made of Forest Products Waste by Fast Pyrolysis. 34(1), 
61-76.

Wibowo, S., \& Hendra, D. (2015). Karakteristik Bio-Oil Dari Rumput Gelagah (Saccharum spontaneum Linn.) Menggunakan Proses Pyrolysis Cepat. Jurnal Penelitian Hasil Hutan, 33(4), 347-363.

ttps://doi.org/10.20886/jphh.v33i4.935.3 47-363

Wijayanti, W., \& Sasongko, M. (2012). Reduksi Volume Dan Pengarangan Kotoran Sapi Dengan Metode Pyrolysis. Rekayasa Mesin, 3(3), 4040-4410.

Wu, W., Mei, Y., Zhang, L., Liu, R., \& Cai, J. (2015). Kinetics and reaction chemistry of pyrolysis and combustion of tobacco waste. Fuel, 156, 71-80. https://doi.org/10.1016/j.fuel.2015.04.01 6

Xia, Q., Yan, B., Wang, H., Xu, J., Zhang, S., Zhou, G., Hu, A., Jiang, J., Xu, S., Wang, J., \& Chen, W. (2020). Production of biooils enriched with aroma compounds from tobacco waste fast pyrolysis in a fluidized bed reactor. Biomass Conversion and Biorefinery. https://doi.org/10.1007/s13399-01900578-z

Yan, B., Zhang, S., Chen, W., \& Cai, Q. (2018). Pyrolysis of tobacco wastes for bio-oil with aroma compounds. Journal of Analytical and Applied Pyrolysis, 248-254. https://doi.org/10.1016/j.jaap.2018.09.01 6

Yang, Y., Chen, X., Wang, D., Cheng, G., \& Lv, D. (2019). TGA analysis of tobacco rob pyrolysis and release characteristics of noncondensable gas in a fixed-bed reactor. International Journal of Green Energy, 16(5), 378-385. https://doi.org/10.1080/15435075.2019. 1572608

Yang, Z., Zhang, S., Liu, L., Li, X., Chen, H., Yang, H., \& Wang, X. (2012). Combustion behaviours of tobacco stem in a thermogravimetric analyser and a pilotscale fluidized bed reactor. Bioresource Technology, 110, 595-602. https://doi.org/10.1016/j.biortech.2011.12. 119

Yıldiz, Z., \& Ceylan, S. (2019). Pyrolysis of tobacco factory waste biomass. Journal of Thermal Analysis and Calorimetry, 2019(136), 783-794. https://doi.org/https://doi.org/10.1007/s109 73-018-7630-z

Yusrizal, \& Idris, M. (2016). Memproduksi Bahan Bakar Gas. Jurnal Inotera, 1(1), 5763. 